\title{
Omar Khadr, Hannah Arendt, and the Racialization of Rights' Discourse
}

\author{
VALENTINA CAPURRI \\ Ryerson University, Canada
}

\begin{abstract}
In this paper, I focus on the story of Omar Khadr, a Canadian minor who was held captive in Guantanamo Bay for a decade, to demonstrate that, at times, neither citizenship nor human rights offer any protection to those who, like Khadr, are citizens of a country and are certainly human beings, yet have been deprived of the rights associated with those statuses. By drawing on Hannah Arendt's argument in The Origins of Totalitarianism, as well as some of her subsequent work, I critically assess the debate regarding whether the rights conferred upon citizens are the only true barriers against abuse, or whether human rights have become a more effective protection. I suggest that this debate is sterile as it fails to recognize that the issue is not which set of rights offers a better guarantee of protection, but how the discourse around citizenship and human rights remains racialized, to the point where certain individuals are considered neither citizens nor humans, and therefore are potentially subject to abuse. Focusing on Canada's treatment of Khadr, I argue that racialization is the root cause of his denial of rights. My analysis aims to contribute to existing literature by refocusing the "rights debate" to demonstrate that any discussion around abstract rights fails to address the experiences of those racialized subjects whose rights have been denied.
\end{abstract}

KEYWORDS citizenship; human rights; racism; racialization; Khadr; Arendt; Canada; Islamophobia

Few in Canada are unaware of Omar Khadr, the story of his capture in Afghanistan on July 27, 2002, and the subsequent ordeal that brought him back to Canada in 2012. In fact, Khadr's case has polarized the Canadian public for over a decade, between those who believe in his innocence and those who consider him to be a terrorist (Angus Reid poll, September 2, 2009). This paper goes beyond recounting once more the story of a 15 yearold Canadian citizen who was imprisoned in Guantanamo Bay for most of his life, nor do the following pages discuss his culpability or innocence. Instead, 
I use Khadr's story to demonstrate that, at times, neither citizenship rights nor human rights offer any significant protection to those who, like Khadr, are citizens of a country and are certainly human beings, yet have been deprived of the rights associated with those statuses. By drawing on Hannah Arendt's argument in The Origins of Totalitarianism, as well as some of her subsequent work, I critically assess the debate regarding whether the rights conferred upon citizens are the only true barrier against abuse, or whether human rights have become a more effective protection. I suggest that this debate is sterile as it fails to recognize that the issue is not which set of rights offers a better guarantee of protection, but how the discourse around citizenship and human rights remains racialized, to the point where certain individuals are considered neither citizens nor humans, and therefore are potentially subject to abuse. My use of the term "racialization" is drawn from the definition of the concept provided by Backhouse (1999, p. 148): "the process by which attributes such as skin colour, language, birthplace and cultural practices are given social significance as markers of distinction."

Focusing on Canada's treatment of Khadr, I argue that racialization is the root cause of his denial of rights. My analysis aims to contribute to existing literature by refocusing the "rights debate" to demonstrate that any discussion around abstract rights fails to address the experiences of those racialized subjects whose rights have been denied. Several scholars have tried to use geopolitics to explain the lack of involvement shown by the Canadian government in Khadr's case, arguing that Canada refused to protect one of its own because of a need to maintain good relations with the United States (US) (Badhi, 2007; Khan, 2012; Pardy, 2012). Although such geopolitical considerations may have played a substantial role in determining Canada's response, I argue that racialization was a much bigger factor in shaping the behavior of Canadian institutions and the Canadian public. As Macklin (2012, p. 225) points out, the large majority of the Canadian public "knew it [his incarceration and mistreatment] was illegal and did not care." There was a deeply rooted understanding in the Canadian psyche regarding who was worthy of belonging and who may be considered disposable. As I will demonstrate in the following pages, the Canadian government's response rested on a racialized understanding of citizenship and human rights.

I begin with a brief overview of Khadr's ordeal, questioning the refusal of the Canadian government to protect his rights as a Canadian citizen and exposing the inefficacy of human rights in providing a valid alternative. I then analyze Arendt's argument in The Origins of Totalitarianism, and her subsequent work, with respect to the failure of both citizenship and human rights to protect certain individuals. I reflect on whether Arendt's work remains valuable today, in light of the supposed erosion of state power due to globalization and in the face of repeated calls to substitute the concept of citizenship rights with the seemingly more encompassing concept of human rights. I suggest that neither set of rights have achieved their intended outcome because they operate within a historical and social context 
dominated by racialized thinking. My conclusion revisits the Khadr case and connects it to the wider discussion around the significance of a citizenship and/or human rights discourse both in Canadian and international contexts.

\section{Omar Khadr}

Omar Khadr is the son of Ahmen Said Khadr and Maha Elsamnah. He was born on September 19, 1986 in Toronto, Canada. His name acquired notoriety after he was captured in Afghanistan in 2002 and accused of having thrown the hand grenade that killed U.S. Sgt. $1^{\text {st }}$ Class Christopher Speer. In October 2002, Khadr was transferred from the US Bagram Airforce base detention facility in Afghanistan to Guantanamo Bay, Cuba, and held in captivity throughout the following decade. On October 25, 2010, he pleaded guilty to the five war crime charges of killing Christopher Speer, spying, attempted murder, provision of material support for terrorism, and conspiracy (Andy Knight \& McCoy, 2012). Under a diplomatic agreement between the American and Canadian governments, he was granted repatriation to Canada after an additional year in Guantanamo. Khadr was transferred to Canada on September 29, 2012 and initially held at the Millhaven maximum security facility in Ontario. After being threatened by another detainee, he was moved to the Edmonton Institution in Alberta at the end of May 2013 (Shephard, 2013). In December of the same year, Khadr was reclassified as "medium security" and transferred to Bowden Correctional Institution (Free Omar Khadr Committee, 2013). On May 7, 2015, Omar Khadr was released on bail and is currently living with his lawyer's family in Edmonton, Alberta. While the previous government of Stephen Harper had initially appealed the Alberta court's decision to grant bail, the current Liberal government has recently announced it will drop that appeal (Perkel, 2016).

There are two main reasons why Khadr received sustained media attention. The first was his age - 15 years at the time of capture - and the US government's insistence to prosecute him as an adult rather than a juvenile, in disregard of the 1989 United Nations Convention on the Rights of the Child (CRC), as well as the 2000 Optional Protocol on the Involvement of Children in Armed Conflict. The US is a signatory of the CRC but has not ratified it. The second reason was that Khadr is a Canadian citizen, and although Canada ratified the CRC in 2001, the Canadian government stood "virtually alone in its support of Guantanamo Bay, while other Western governments have condemned the prison and managed to bring their citizens home" (Shephard, 2008, p. xiv). Canada was in fact complicit in the detention of one of its citizens, as Canadian Security Intelligence Service (CSIS) agents were sent "to interrogate Khadr under the pretext of aiding him and then turned the contents of that interview over to the US" (Engler, 2012, p. 183). Through its cooperation with the US government, Canada violated Khadr's rights as a citizen. 
This paper touches only tangentially on the debate around the juvenile status of Khadr at the time of his capture. Whereas the issue was debated in Canada, particularly after being publicized by then Senator Romeo Dallaire, a long-time advocate on behalf of child soldiers, it is not my objective in this paper to discuss whether Omar Khadr should be considered a child soldier. Whether he was considered a child or an adult, the Canadian government would still have an obligation to uphold his rights as a citizen. Furthermore, I consider the notion of child soldier to be extremely problematic as it rests on a westernized understanding of childhood, and it has been increasingly used as a colonial tool adopted by Western powers to intervene in those parts of the world, mainly the African continent, where inhabitants are not considered to be "civilized enough" to value and protect their children (Hyndman, 2010). In this paper, the issue of child soldiering is only mentioned for its significance in highlighting that any United Nations (UN) convention or document is unenforceable unless it receives the support of individual states. The fact that Canada refused to demand adherence to the convention as it applied to one of its citizens demonstrates the unenforceability of international human rights agreements.

The complicity of the Canadian government, under both the Liberals and the Conservatives, in the persecution of Omar Khadr and his confinement in Guantanamo Bay was exposed in 2005. In granting Khadr's lawyers an interim injunction halting CSIS visits to Guantanamo, Federal Court Justice Konrad Von Finckenstein concluded that "conditions at Guantanamo Bay do not meet Charter standards" (Shephard, 2008, p. 167). The court ruling was a further reminder that, guilty or innocent, Omar Khadr should have enjoyed inalienable Charter rights that were being violated in Guantanamo. This injunction did little to prevent comments such as those expressed by Ezra Levant (2011, p. 79) that "the United States, Omar Khadr's jailer, hardly qualifies as a country unable to fairly dispense the rule of law" and it is therefore a jurisdiction where Canada has no legitimate reason to intervene. This argument deserves only a passing mention as the Guantanamo Bay military complex is outside the legal jurisdiction of the US, and that is why it was chosen by the Bush administration as a detention camp for enemy combatants. Reports prepared by the Red Cross and other witnesses indicate that Guantanamo detainees are regularly abused and tortured (Edney, 2012). By refusing to intervene on Khadr's behalf, successive governments acted unconstitutionally as, the Charter establishes that Canadian citizens are entitled to the right to counsel, protection from torture and a fair trial.

The argument that Canada had little authority in deciding the fate of Khadr also lacks substance. As I discuss in the following sections, even in the global age, states retain substantial authority in controlling their own population. While Nathalie Des Rosiers (2012), General Counsel of the Canadian Civil Liberties Association, is correct in pointing out that Canadian law is unclear when it comes to the government's exact responsibilities towards its citizens who are arrested, tried or incarcerated abroad, it should be acknowledged that 
other Western governments have been successful in putting pressure on the US to release their citizens from Guantanamo. For instance, Michelle Shephard recounts the "Fair Go for David" campaign that was started by the father and military lawyer of David Hicks, an Australian held in Guantanamo. The campaign forced then Prime Minister John Howard, a strong Bush ally, to intervene on Hicks' behalf with US Vice President Cheney. The result was a swift deal that saw David Hicks plead guilty in exchange for a sentence of nine months in an Australian jail (2008). In Canada, neither the Liberal nor Conservative governments cared enough to repatriate a Canadian citizen locked in the legal limbo that is Guantanamo Bay. It also did not help that the Supreme Court of Canada refused to force any remedial action on the government (Davidson, 2012).

While the Canadian government failed to uphold Khadr's citizenship rights, the international community was equally unsuccessful in protecting Khadr's human rights. Despite the public advocacy of several human rights organizations, such as Amnesty International, Human Rights Watch, UNICEF, Coalition to Stop the Use of Child Soldiers, and Lawyers Against War, little changed in Omar Khadr's life behind bars (Khan, 2012; Williamson, 2012). This suggests that human rights remain ineffective due to the international community's refusal to enforce restrictions and hold accountable violators of those rights (Blau \& Moncada, 2009; Davidson, 2012). In the case of Khadr, neither citizenship nor human rights offered any protection from forced confinement and abuse. How did it happen that Canadian governments of different political orientations were given carte blanche to abandon their own citizen for over a decade? How could it be that, in the age of human rights, no one has been held responsible for the lives that were lost and forgotten in Guantanamo? What set of rights should we appeal to in situations such as the one discussed in these pages? Are human rights more or less effective than citizenship rights? What if neither proves to be of any help? Over 60 years after the publication of The Origins of Totalitarianism, Arendt's (1976) discussion of citizenship and human rights might still provide some guidance in answering these questions.

\section{Hannah Arendt and The Origins of Totalitarianism}

Hannah Arendt's The Origins of Totalitarianism (1976) was first published in 1951. The book is divided into three parts: "Antisemitism," "Imperialism" and "Totalitarianism." In the first two parts Arendt focuses on the constitutive elements of antisemitism and imperialism, in the belief that those elements were at the root of the totalitarian movements that emerged in the 20th century (Kohn, n.d.). In the third part, she analyzes the phenomenon of totalitarianism. As Arendt (1976, p. viii) explains in the preface to the first edition, her effort aims at comprehending not by simplistic recourse to causation but by "examining and bearing consciously the burden which our 
century has placed on us" (1976, p. viii). Her going back to the origins of totalitarianism is an attempt to resist a reality that should never have been yet was. In "The Decline of the Nation-State and the End of the Rights of Man," which concludes part two of her book, Arendt discusses the decline of the nation state in Europe and its consequences for those who, before or after World War II, were dispossessed of their rights as citizens and left stateless and rightless, "the scum of the earth" (1976, p. 267). When pointing out the failure of the nation state system, Arendt was also skeptical of the notion of human rights and its efficacy in protecting either groups or individuals (Thobani, 2007).

Omar Khadr was born in Canada; accordingly, he has legal citizenship status. Despite this incontrovertible reality, he has been practically deprived of some of his rights as a citizen by successive Canadian governments. By leaving him in Guantanamo Bay, Canada ignored its obligation to protect Canadians abroad (Pardy, 2012). As argued by Audrey Macklin, "Canada effectively renounced its relationship to Omar as citizen" (2012, p. 233) and only took him back under pressure from the Obama administration. For all practical purposes, Canada considered Omar Khadr as an alien. Rather than indicating a weakening of state power in the age of globalization, this ability to pick and choose which citizens are worthy of the status and which are unworthy and therefore remain citizens in name only, reinforces the state's power to control its population. The Conservative government of Stephen Harper went one step further when it introduced Bill C-24, Strengthening Canadian Citizenship Act, which established that Canadian citizenship can be rescinded for dual citizens who are convicted of terrorism-related offences. Bill C-24 became law on June 20, 2014, officially empowering the government to revoke the citizenship status of those dual citizens accused of "bad behavior" (Bahrami, 2016). Not surprisingly, those who have been targeted by this legislation are all Muslim Canadians (The Canadian Press, 2015). The newly elected government of Justin Trudeau has already tabled legislation to repeal the Bill (LEGISinfo, 2016).

Arendt's definition of citizenship as "the right to have rights" (1976, p. 298) confirms that today as in the past, human rights are largely ineffective as a barrier against abuse. Humanity in itself is not enough to guarantee the protection that only a state can demand for its citizens. When people become stateless or, as in the case of Omar Khadr, the state refuses to recognize them as citizens, there is no protection left. Omar Khadr is one example of a pattern emerging in Canada that, particularly since the 9/11 (September 11) attacks in 2001 in the US, has witnessed the government systematically ignoring the rights of its own citizens; Maher Arar, Abdullah Almalki, Ahmad El Maati, Muayyed Nureddin, and Abousfian Abdelrazik are all Canadian citizens who have faced torture abroad with Canada's complicity (Khan, 2012). In none of these cases has Canada willingly provided any support nor has the international community effectively intervened. If we also consider the violations of rights on Canadian soil, from the daily harassment 
of Muslim and Arab Canadians to the detention under security certificates of immigrants with the use of secret evidence, a pattern of abuse emerges that targets specific individuals whose only commonality is their religious or ethnic background.

Canada's failure to protect its own citizens confirms the validity of Arendt's argument that human rights, "defined as 'inalienable' because they were supposed to be independent of all governments," (1976, p. 291) are revealed as unenforceable the moment that no government steps forward to guarantee them. For Arendt, the moment the world population got divided into national groups, each one located within the territorial boundaries of a nation state, human rights became "only meaningful and attainable within the context of citizenship rights" (Rygiel, 2010, p. 48). Andrew Vincent (2010, p. 166) notes that for Arendt, "Outside the framework of states human rights were largely otiose." Giorgio Agamben concurs that within the system of the nation state, human rights reveal their uselessness "precisely when it is no longer possible to conceive of them as rights of the citizens of a state" (2000, p. 20.0). Agamben exemplifies this assertion by recalling how the Nazis made a point of sending Jews and "Gypsies" to extermination camps only after they had been denationalized. The steadfast commitment Nazis showed to this rule was no small bureaucratic directive but essential to the entire edifice of the final solution, since "When their rights are no longer the rights of the citizens, that is when human beings are truly sacred, in the sense that this term used to have in the Roman law of the archaic period: doomed to death" (Agamben, 2000, p. 22.2; see also Arendt, 1976; Agamben, 1998). In Homo Sacer: Sovereign Power and Bare Life, Agamben (1998, pp. 132-134) went back once again to Arendt's analysis and concluded that when "the rights of man" get separated from "the rights of the citizen," they lose their connection to the field of politics and are relegated to the nebulous category of "humanitarianism," that is to perpetual irrelevancy.

Today, as in 1951, a huge hiatus persists between "the efforts of wellmeaning idealists who stubbornly insist on regarding as 'inalienable' those human rights ... and the situation of the rightless themselves" (Arendt, 1976, p. 279). From Afghanistan to Palestine, from Rwanda to Guantanamo Bay, from Burma to Saudi Arabia, human rights violations continue unabated. Despite the protocols, treaties and covenants signed at the UN, international law continues to be limited to the good will of sovereign states to implement them since "for the time being, a sphere that is above the nations does not exist" (Arendt, 1976, p. 298). In On Revolution, first published in 1963, Arendt reiterated her belief that human rights amount to little more than wishful thinking unless they are translated into citizenship rights by their incorporation into state laws. According to Arendt (2006, p. 140), the problem inherent to human rights is that they inevitably have less authority than "the rights of nationals, and that they were invoked only as a last resort by those who had lost their normal rights as citizens." And yet, even as a last resort, human rights have been revealed to be quite futile. 
In the following section, human rights are examined in light of Arendt's (1976, p. 300) claim that "the abstract nakedness of being nothing but human" has had little use for people across the world. The analysis also focuses on the inaccuracy of arguments that imply that processes of globalization have weakened citizenship while injecting new life into human rights. Following Rygiel's (2010) analysis, I maintain that the opposite is true and that, rather than challenging citizenship, globalization is strengthening it, thus making it a more powerful tool in controlling populations within and across borders. Although my argument supports the notion that citizenship is still relevant despite (and because of) the spread of globalization, I suggest moving beyond the debate around citizenship versus human rights, as I consider it unhelpful in addressing situations in which neither citizenship rights nor human rights have provided any protection. In particular, I claim that, as pointed out by Sherene Razack (1998), an exclusive focus on rights is misleading insofar as it centres on the notion of the abstract individual while failing to take into account that individuals are always part of groups that are in evolving power relations vis-à-vis each other. Human and citizenship rights must be understood as operating within a political and social reality of racialization that remains a defining characteristic of organized human life. While both sets of rights might have strengths and weaknesses of their own (something that is beyond the scope of this paper), the problem is that they are applied within racialist dynamics that position some individuals as citizens and human beings, and others as neither citizens nor humans.

\section{The “Citizenship Rights Versus Human Rights" Debate}

The debate around whether we should privilege human rights over citizenship rights, or vice versa, is a recurrent one. Paulina Tambakaki (2009) identifies the basic differences between citizenship and human rights. Among these differences is the fact that human rights are by definition universal, insofar as they apply to all human beings, while citizenship rights are the exclusive preserve of "members of nationally and territorially delimited communities" (Tambakaki, 2009, p. 9). Citizenship rests on the premise of the "stateterritory-identity axis" (Painter \& Philo, 1995, p. 111). As a consequence of its connection to a delimited physical space, citizenship is therefore inextricably tied to the concepts of inclusion and exclusion. Human rights are instead untied to a specific political unit or territory. This universality, which for Arendt rests on the notion of "an 'abstract' human being who seemed to exist nowhere" (1976, p. 291), is among the reasons for the popularity of human rights as well as its failure.

The notion of human rights is attractive. The issue for Arendt was not the appeal of the notion but its efficacy. This has been the case since its appearance in the American Declaration of Independence in 1776 and the French Declaration of the Rights of Man and Citizen in 1789 (Agamben, 
1998; see also Arendt, 1976; Heater, 1999). Despite claims that the articulation of these rights in the Universal Declaration of Human Rights, adopted by the UN General Assembly in 1948, and in subsequent supporting Covenants and Protocols, has given a boost to human rights by bringing a certain level of enforceability through the creation of international law and a plethora of judicial institutions (Faulks, 2000; Heater, 1999), for many people all over the world human rights remain an ideal that has not materialized. As noted by Amy Ross (2008), the expansion of the human rights discourse since the late 1940s has been matched by an even greater expansion in the violation of human rights across the world.

Several of the arguments in support of replacing citizenship rights with human rights rest on the belief that individual states are becoming irrelevant, as economic processes, international migration and "new security dilemmas associated with cross-border threats such as nuclear annihilation or ecological disaster" (Faulks, 2000, p. 150; see also Zizek, 1993) are beyond the reach of national policies and laws (Vincent, 2010) and signal the "unstoppable decline of the nation-state" (Agamben, 2000, p. 16.6; see also Thobani, 2007). The role played by the UN and the permeability of states to the theory and practices of human rights are also presented as signs that state sovereignty is declining (Bosniak, 2001; Faulks, 2000; Heater, 1999; Joppke, 2001; Levy \& Sznaider, 2010). And yet, it is worth recalling that the international law that is supposed to implement these rights is a "soft" law (Joppke, 2001), unenforceable as long as it is administered by states (Fossum, 1999; Vincent, 2010). Even advocates of the human rights discourse such as David Kennedy must concede that "in the end rights are enforced, granted, recognized, implemented, and their violations remedied by the state" (2004, p. 16). Whereas states with little power can be held accountable for ignoring human rights, powerful states are free to set their own standards of accountability. The claim that the UN can guarantee the protection of human rights on a worldwide scale is fictitious because, as Arendt (1976) observed in 1951, the world system operates on the basis of treaties of reciprocity and international agreements.

While the protection of human rights is dependent on the will of individual states, albeit through the mechanisms envisioned by the international community as represented by the UN, these states are positioned on an unequal playing field, some enjoying more power than others. Powerful states are guaranteed impunity for their human rights violations, while weaker states are prosecuted and eventually punished (Falk, 2009). Noam Chomsky (2012, p. 161) comments that "Throughout history, few principles of international affairs apply generally. One is the maxim of Thucydides that the strong do as they wish while the weak suffer as they must." The consequence of discriminating among states based on their de facto power is the watering down of the significance of human rights.

Among the states that are systematically granted impunity, the case par excellence is the US, whose government has, throughout history "done little 
but obstruct progress of the international human rights framework" (Blau \& Moncada, 2009, p. 5; see also Hitchens, 2012). The US has never ratified any human rights treaty without the qualifier that the treaty is not "selfexecuting," meaning it does not apply to the US. In terms of accountability, the US has put itself outside the reach of the International Criminal Court (ICC) (Blau \& Moncada, 2009). A similar level of impunity is also granted to US allies. Richard Burchill (2008) notes that the current system of international human rights law continues to prioritize state interests over the promotion and preservation of human rights. Certain states can and do act as they please without incurring any legal consequences.

With respect to the claim that globalization is weakening the state, it is worth noting that, although globalization might force individual states to review and adjust the way in which they operate, "the individual overwhelmingly continues to be caught in a statist web of rights, duties, and identities" (Falk, 2009, p. 72). As Rygiel points out, globalization has increased rather than diminished citizenship as a "regime for governing individuals, populations, and their movement between and across borders" (2010, p. 12). National governments are allowed to select who, within their populations, is worthy of recognition as a political subject with rights and who should be, as in the case of Omar Khadr, deprived of those rights. The state maintains its ability to exercise power over and above any international institution devoted to the protection of human rights. The ability of the sovereign state "to shun a person from the political community" (Rygiel, 2010 , p. 105) remains entirely preserved. Sunera Thobani (2007, pp. 238239) shows how, after the events of $9 / 11$, "the Muslim strangers within, even if claiming the legal status of citizens, come to be construed as ... the threat to the nation." This perceived threat allows the state to selectively pinpoint certain Muslim citizens as dangerous and to practically suspend some of their rights as citizens. The moment individuals are deprived of "the rights that should be theirs by virtue of citizenship" (Rygiel, 2010, p. 157), they end up losing their political subjectivity and are, according to Agamben (1998, p. 142), reduced to bare life "which may be killed but not sacrificed." Guantanamo Bay, Khadr's home for over a decade, is among the principal theatres where citizens have been systematically "unmade," their identity as political subjects erased, recognition as citizens of a particular country denied, and their ability to claim rights under international law as Prisoners of Wars (POWs) lost (Gregory, 2007; Rygiel, 2010).

Globalization has strengthened rather than weakened the power of the state. Whereas citizenship has always been defined in gendered and racialized terms (Faulks, 2000; Thobani, 2007), current processes of globalization have increased the state's ability to manipulate racial categories to deprive citizens of some of their rights. Omar Khadr is among those individuals who the state has decided do not belong, and have therefore been transformed into what Jasmin Zine (2012, p. 392) defines as "disposable citizen[s]." The rights of these citizens are precarious at best. Despite their legal status, some are 
assumed guilty by reason of their race or ethnicity, and are left with the task of proving their innocence in order to be recognized as citizens.

The above points indicate that, while human rights are an appealing concept, they are largely unenforceable. On the other hand, whereas citizenship rights constitute a more reliable source of protection, they continue to depend on the willingness of the state to recognize the individual as a worthy citizen. This recognition is caught within a racialized framework that assesses as unworthy those individuals who are perceived as racial "others." In the following section, I discuss how human and citizenship rights have been subjected to racialist dynamics that have resulted in their irrelevancy for a significant number of groups and individuals in Canada and across the globe, particularly but not exclusively in the climate of post-9/11 hysteria.

\section{The Racialization of Human and Citizenship Rights}

The racialization of the other is not a new phenomenon. In The Origins of Totalitarianism, Arendt $(1976$, p. 158, 160) argues that race-thinking, which developed throughout the $18^{\text {th }}$ century, "emerged simultaneously in all Western countries during the $19^{\text {th }}$ century" as "the main ideological weapon of imperialistic politics." By emphasizing the connection between racethinking and political needs, Arendt (1976, p. 159) reclaims ideology as a "political weapon" rather than a "theoretical doctrine," thereby distancing it from the realm of the abstract and re-immersing it into the historical and political context. Race was the tool that imperialism adopted in order to deny a common humanity between the White man and those he colonized. From the beginning, the nation "conceived of its law as an outgrowth of a unique national substance which was not valid beyond its own people and the boundaries of its own territory" (Arendt, 1976, p. 127), and therefore did not apply to the less-than-human colonized overseas. Over time, the immigration of the colonized other forced nations to face the problem of a population that could still be considered beyond its own people but was certainly no longer beyond the boundaries of its own territory. The response to this problem was a reassessment of the concept of citizenship so that it applied differently to nationals and outsiders, irrespective of legal status.

Michel Foucault (2003, p. 257) concurs with Arendt that the emergence of a racialist discourse goes back to colonization, where it found expression in "colonizing genocide." Although Foucault (2003, p. 256) defines racism as the "precondition for exercising the right to kill," he specifies that the term "killing" is not exclusively in reference to "murder as such" but also to "political death, expulsion, rejection, and so on." These actions were justified with the introduction "within the biological continuum of the human race of races, the distinction among races, the hierarchy of races, the fact that certain races are good and that others, in contrast, are described as inferior" 
(Foucault, 2003, pp. 254-255). Foucault's insights into the origins of racism are helpful in understanding why a discourse on human and/or citizenship rights cannot escape being situated within a context where individuals are automatically defined as belonging to particular races. Foucault's analysis details how race is at the core of the political structures that were built on the exploitation and colonization of other people. Such colonization and exploitation could not have occurred without a pre-existing race discourse that allowed some individuals and groups to be considered as less-thanhuman.

Even before the events of 9/11, nation states used nationalism as a tool to create "narrow perimeters around community" through processes of exclusion and inclusion (Davis, 2012, p. 73). In Canada, racism has been at the core of the nation, and as noted by Constance Backhouse (1999, p. 15), "resonates through institutions, intellectual theory, popular culture, and law." Despite national mythologies that portray Canada as a "nation innocent of racism," Dua, Razack and Warner (2005, p. 1; see also Jiwani, 2005) point out that the country has been built on a long "history of colonization, slavery, and discriminatory immigration legislation." The Indian Act of 1876, for example, stated that the word "person" did not include someone who was "Indian" (Backhouse, 1999, 2005). Racism is also central to the country's relationship with individuals coming from outside of its borders. Canada has relied on the racialized category of immigrant in order to "sustain the myth of the nation as homogeneous, by constructing as perpetual strangers those to whom the category is assigned, even when they are second or third generation Canadian-born citizens" (Thobani, 2007, p. 76). Reem Bahdi (2007, p. 81) maintains that throughout Canadian history, what demarcates the distinction between "those who are imagined to belong to the community" and foreigners is not citizenship but racialism. An example of this is the suspension of citizenship and the internment of Japanese Canadians during World War II. For seven years, from 1942 to 1949, the racial identity of Japanese Canadians became "more significant than their citizenship status" (Bahdi, 2007, p. 94). Citizenship had, therefore, been transformed into a category that had meaning for certain groups and individuals but not for others.

Racialization dynamics work within an ideological context that understands the nation as a possession that some people have and which others want and threaten to steal. Zizek (1993, p. 201) points out that this "Nation-Thing," which is often erroneously reduced to a "way of life," gets conceived of "as something accessible only to us, as something 'they,' the others, cannot grasp; nonetheless is something constantly menaced by 'them'." In Canada, "the historical racialization of the category of citizen" has resulted in a situation that allows some citizens to "claim nationality while others are denied such claims, even when they share the legal status of citizenship" (Thobani, 2007, p. 100; see also Razack, 2010). By looking at the situation of Muslim Canadians in the immediate aftermath of 9/11, Jiwani 
(2005) details how they were given no opening in the media to demonstrate their commitment to their new country, but were instead consistently identified as others who came here to take advantage of better economic conditions. Their being Canadian was therefore framed, not as a matter of belonging or loyalty, but as simple opportunism. Far from providing equality, multiculturalism, one of the core Canadian myths, has been used to obscure "the relations of racialized power and privilege that shape the nation" (Zine, 2012 , p. 399). Citizenship is therefore subordinated to a racialization process that can either offer legitimacy (for Whites) or different degrees of exclusion (for everybody else), and seems to matter very little "when it comes to the colour line" (Jiwani, 2011, p. 18). If we look at the definition of killing offered by Foucault, this is what racialization has done to those citizens who were not perceived of as nationals. In fact, we are increasingly witnessing those citizens' political exclusion from the national body, irrespective of the legal status they continue to possess.

Racism has a long history, but it "is not static. It changes. It mutates. It gets altered by historical circumstances" (Davis, 2012, p. 99). After World War II and the horrors of Nazism, the variant of racism resting "on the notion of biologically based inferiority" was no longer popular (although it did not disappear altogether) and was reinvented into what Sherene Razack (1998, p. $60 ; 2008)$ calls the "culturalization of racism," whereby non-white groups are no longer blamed for their biological make-up but for their cultural and acquired traits. Evan and Giroux (2015, p. 113; see also Gilroy, 1991; Jiwani, $2005,2011)$ note that "the concept of race as biologically determined has been subsumed within religious and cultural narratives." This form of racism is no less damaging than its former version. Dominant groups no longer exclude others based on a presupposed constitutional inferiority, but instead because their culture is perceived of as being deficient and unable to adequately fit within the national environment. The nation is presented as multicultural, yet it must be understood that such multiculturalism is accepted and maintained only insofar as its structuring hierarchical power relations remain unchallenged.

The events of 9/11 in the US represent another juncture where racism "gets altered by historical circumstances" (Davis, 2012, p. 99). The aftermath of 9/11 witnessed racism being "fundamentally reconfigured" so as to incorporate "ideologies of terrorism," with the result that people profiled as Arabs or Muslims were expelled from the "circle of the nation" (Davis, 2012, pp. 94-95). Far from representing a departure, this reconfiguration continues to rely on "the historical processes of racialization associated with colonialism, imperialism, Eurocentrism" (Dua et al., 2005, p. 6). Whereas the targeting of Muslims in the West is an old phenomenon, as indeed Edward Said (1981) pointed out well before the attacks on the Twin Towers and the Pentagon (i.e., 9/11), the discourse about the threat Islam represents to Western civilization has been entrenched into the national psyche in the aftermath of those events. Arab, South Asian and Muslim men have been 
represented as coming from a foreign culture that "produces individuals with an inherent capacity for violence" (Razack, 2008, p. 29; emphasis added), who therefore must be contained, under surveillance, and repressed.

The war waged against Islam, "the quintessential Other of the West," has reconfigured the Muslim as a category that is not only religious and political but, above all else, racialized (Thobani, 2007, p. 235). The reason for this racialization is that, as Foucault (2003) noted back in 1976, racism is the precondition for exercising the right to kill. The killing of the person as a political subject is what we have witnessed in the case of Omar Khadr. Because of the way Canada has chosen to racialize Khadr's body, he has been presented to the Canadian public as dangerous and unworthy of those rights that are legally his by birth. As Zine suggests, "The corporeality of belonging is colour coded" (2012, p. 393). It is therefore apparent that citizenship does not offer equal protection to all citizens, certainly not to Muslim citizens, who have been cast out as a threat to the survival of the nation and continue to be portrayed as not belonging.

The "War on Terror" started by George W. Bush after the attacks of 9/11 has a clear racial character. The US and the other countries that joined in (including Canada) have dismissed accusations of racism by bringing into the national fold those same citizens who have been historically criminalized, oppressed and marginalized. As noted by Eric N. Olund (2007, p. 71), one of these attempts to disempower claims of racism has been the US military's proud display "of African-Americans and Hispanic Americans in its ranks." The myth of multiculturalism in Canada has played a similar role in disputing accusations of racism. And yet, race and racism are at the core of the War on Terror, and integral to the policies and practices developed in Western countries to regulate, contain, and marginalize certain populations. It is racialization that has allowed the invasion of countries inhabited by nonwhite populations and the targeting of persons of Middle Eastern or South Asian background back home (Olund, 2007). Lisa Marie Cacho (2012, p. 5), for example, discusses how racialized persons in the US (this also applies to Canada) are "differently included" within the legal system in that "Although they are excluded from law's protection, they are not excluded from law's discipline." This refusal to protect yet willingness to punish under the law therefore sanctions and legitimizes "the state's monopoly on violence" at the expense of "justice, empowerment, or equality" (Cacho, 2012, p. 142).

Racialization is also apparent in the infamous pictures of abuse of Iraqi prisoners by US soldiers at Abu Ghraib, pictures that, as many commentators have noted, were meant as souvenirs and were shockingly reminiscent of pictures taken by White Americans who lynched Blacks on US soil in the decades after the Civil War (Evans \& Giroux, 2015). In Canada, racialization appeared to underlie Operation Thread, which in August 2003 led to the arrest of 22 Pakistanis and one Indian national in the Greater Toronto Area as potential terrorists only "because of their ethnic and religious backgrounds" (Odartey-Wellington, 2009, p. 35). As Odartey-Wellington (2009) claims in 
his analysis of Operation Thread, the events of 9/11 reactivated the old trope of "Muslim terrorism," by creating a moral panic that spread to Canadian society, from the media to the public to the security apparatus. This moral panic generated unfounded fears of terrorism solely "based on the racial profiles of the suspects" (Odartey-Wellington, 2009, p. 29).

If citizenship rights fail to offer protection, human rights have not performed any better for exactly the same reasons. As discussed in the previous section, human rights are predicated on the belief of a common humanity. However, the rhetoric around a common humanity is an abstraction. Racialization systematically and pervasively breaks down that commonality. An essential part of the racialization dynamics we see at work in Western societies is "the denial of a common bond of humanity between people of European descent and those who are not," and the consequent inapplicability of any law, whether international or national, to "those marked outside humanity" (Razack, 2008, p. 6). Non-Westerners are described as "animal-like, and hence as implicitly less-than-human," while Westerners are perceived of as "fully human" (Thobani, 2007, p. 235) and deserving of the protection of the law. In Canada, for instance, Razack (2000) has shown how the events that followed the Canadian peacekeeping mission to Somalia in 1992 - events that saw Canadian soldiers beat, torture, and murder at least three Somalis on two different occasions - illustrate the racialist understanding those soldiers and the Canadian public back home applied to the notion of human life. In the Somali affairs, Razack uncovers the way the Canadian mythology of innocence and tolerance was opposed to constructions of Somalia and its inhabitants as inherently dirty, violent, and dangerous, and was employed to morally absolve Canadian troops of their brutality and criminality. Who could point the finger at innocent peacekeepers sent unprepared to withstand the chaos of an inhospitable land? "Our" soldiers were human beings in a difficult situation, while the murdered Somalis were others to whom the concept of humanity didn't seem to apply.

If human rights and citizenship rights are revealed as ineffective, is there any alternative? I do not have an answer but I think that, once again, Arendt might offer some guidance. As discussed above, Arendt (1976, p. 293) believed that the "Rights of Man, supposedly inalienable, proved to be unenforceable." Her critique of human rights stems from the conviction that rights are not given to individuals the moment they are born but can only "be found within the context of a polity" (Butler, 2012, p. 143). What should this polity look like? According to Arendt, it must be something other than the nation state, since the citizenship rights conferred by the nation state have been proven to only work for some. Arendt understood that, within the system of the nation state, non-nationals and minorities were inherently excluded from the enjoyment of citizenship rights. I believe this is true for states, such as Canada, which claim to be multicultural.

As noted by Judith Butler (2012, p. 145), Arendt, in The Origins of Totalitarianism, never really addresses what the alternative to the nation state 
might look like, but in some of her subsequent works she "offers us a few comments on 'federations' that suggest she thought something might come of them." In Men in Dark Times (1068, p. 93), for instance, Arendt writes that for Karl Jasper, her mentor and friend, the only political solution that could bring salvation to the world rested on "a framework of universal mutual agreements, which eventually would lead into a world-wide federated structure" (Arendt, 1993, p. 93). This new political structure would replace the nation state and its reliance on sovereignty, in order to bring forward a new mutual understanding among all people that "would be renunciation, not of one's own tradition and national past, but of the binding authority and universal validity which traditions and past have always claimed" (1993, p. 84). For Arendt, this federated structure was not simply a way to distribute sovereignty among different nations but to get rid of sovereignty altogether.

In the summer of 1970, in an interview with German writer Adelbert Reif, Arendt (1973, p. 230) suggested again the need for a "new concept of the state," one that not only distances itself from the sovereign state but also from "a new League of Nations," the latter being destined to be either ineffective or "monopolized by the nation that happens to be the strongest." Explaining what such a new polity might look like, she came back to Jasper's idea of a federation where "power moves neither from above nor from below, but is horizontally directed so that the federated units mutually check and control their power" (Arendt, 1973, p. 230). This federated political structure was inherently different from the nation state, insofar as it was constituted on the idea of equality among members irrespective of their national belonging, as belonging, although a "requirement of human life . . can never serve as a legitimate basis for a polity" (Butler, 2012, p. 149). Arendt (1973, p. 233) was aware that the chances for such a new system to be realized were "very slight, if at all" (p. 233). And yet, almost a half-century later, faced with the failure of the supranational authority of the UN and with a state power that does not necessarily leave people stateless but can take away their rights, we might want to reconsider her suggestion of a new polity. It might still be an unlikely outcome, but the risk might be worth taking.

\section{Conclusion}

In this paper, I began by examining the ordeal of Omar Khadr, a Canadian citizen captured in Afghanistan and held for a decade in Guantanamo Bay by the US with the complicity of the Canadian government. I used the Khadr case to delve into the debate around the primacy of citizenship or human rights as effective tools for the protection of individuals. Drawing on the analysis provided by Hannah Arendt in The Origins of Totalitarianism, I claimed that this debate is sterile, and attempted to move the discussion beyond the abstract human rights versus citizenship rights framework, 
repositioning it instead in a political, social and historical context that racializes any understanding of rights.

In order to validate my argument, I demonstrated that, as revealed in the case of Omar Khadr, neither citizenship nor human rights have any significant impact in protecting the lives of racialized persons. Human rights, as appealing as the notion might be, are largely ineffective in a world where the principle of state sovereignty continues to be given unquestioned priority. International law remains a "soft law" that only gets applied vis-à-vis weaker states. More importantly, I have shown that the concept of human rights, based on the ideal of a common humanity that we all share, is bound to fail unless we address the reality of a world where people are not born equal and with the same rights, but are instead always situated within a racialized framework that considers some individuals as humans and others as lessthan-human.

With respect to citizenship rights, the discourse is more complicated yet the conclusion is similar. Whereas I agree with Arendt that, as a political tool, citizenship enjoys greater authority than human rights, we must acknowledge that citizenship increasingly offers protection on the basis on nationality rather than status. In this paper, I first addressed recent claims that globalization has resulted in a weakening of state power. I argued that the opposite is true: notwithstanding the need for some adjustment, the state has kept unaltered the ability to control its own population. Whereas state power has remained intact, the state does not necessarily protect its citizens because of an abstract notion of rights associated with citizenship status. Evidence indicates that state power is increasingly used to enable states to decide who is worthy of recognition as a deserving citizen and who, despite having the legal status of a citizen, is not. As my analysis has shown, this decision is made on the basis of racialist considerations. Omar Khadr is a classic example of a citizen by birth, who because of the racialist dynamics at work in Canada has been branded as undeserving. This indicates that although in the international system state sovereignty continues to remain a priority, there is no guarantee that citizenship rights will be able to protect those who enjoy the legal status of citizen.

Following Arendt's argument, I believe it is time to move beyond the abstract human rights versus citizenship rights debate, and start analyzing how both sets of rights remain trapped within racialist dynamics that allow some of us to be considered as human beings and some of us as undeserving of that title. If, as I think, this racialist framework is our current reality, an alternative could be found, as Arendt suggested, in developing a new political structure that is separate from both the state and supranational organisms such as the UN. This new structure would instead look like a federation made up of different people with equal rights. If, as Arendt argued, we accept that "we may not choose with whom to cohabit" this world, "but that we must actively preserve the unchosen character of inclusive and plural cohabitation" (Butler, 2012, p. 151), we might still have a chance to create a global 
community that shares one, interconnected, interdependent planet. This means that we must acknowledge the racialist framework at the core of human as well as citizenship rights, and recognize how their unequal application results in a situation of disadvantage for racialized persons. We also need to acknowledge that individuals have different belongings, and because of, rather than despite of, their different belongings, they have the right to live free from abuse or persecution. If we accept that plurality is not simply something we tolerate, but a reality we have a social, political and ethical obligation to protect, maybe we still have a chance for survival on this planet.

\section{References}

Agamben, G. (1996/2000). Beyond human rights. In Means without end: Notes on politics (V. Binetti \& C. Casarino, Trans.) (pp. 2.15-2.28). Minneapolis, MN: University of Minnesota Press.

Agamben, G. (1998). Homo sacer: Sovereign power and bare life. Stanford, CA: Stanford University Press.

Andy Knight, W. \& McCoy, J. (2012). International law and the recruitment of a child soldier: Omar Khadr and family ties. In J. Williamson (Ed.), Omar Khadr, Oh Canada (pp. 285304). Montreal \& Kingston: McGill-Queen's University Press.

Angus Reid Strategies (2009, September 2). Canadians evenly divided on Omar Khadr. Retrieved from https://www.angusreidforum.com/MediaServer/3/documents/2009-09-02Khadr.pdf

Arendt, H. (1951/1976). The origins of totalitarianism. Orlando, FL: Harcourt Books.

Arendt, H. (1963/2006). On revolution. London: Penguin Books.

Arendt, H. (1968/1993). Men in dark times. Orlando, FL: Harcourt Books.

Arendt, H. (1970/1973). Crisis of the republic. Orlando, Florida: Harcourt Books.

Backhouse, C. (1999). Colour-coded: A legal history of racism in Canada, 1900-1950. Toronto: University of Toronto Press.

Backhouse, C. (2005). What is access to justice? In J. Bass, W.A. Bogart \& F.H. Zemans (Eds.), Access to justice for a new century: The way forward (pp. 113-146). Toronto: Law Society of Upper Canada.

Bahdi, R. (2007). Constructing non-citizens: The living law of anti-terrorism in Canada. In J. Hocking \& C. Lewis (Eds.), Counter-terrorism and the post-democratic state (pp. 81-100). Cheltenham, UK \& Northampton, MA: Edward Elgar.

Bahrami, S. (2016, February 18). Critical review of the new Canadian Citizenship Law Bill C24. SFU Centre for Education, Law, and Society. Retrieved from http://www.sfu.ca/education/cels/bilingual/bilingual-corner/bill-c-24.html

Blau, J., \& Moncada, A. (2009). Human rights: A primer. Boulder, CO: Paradigm Publishers.

Bosniak, L. (2001). Denationalizing citizenship. In T.A. Aleinikoff \& D. Klusmeyer (Eds.), Citizenship today: Global perspectives and practices (pp. 237-253). Washington, DC: Brookings Institution Press.

Burchill, R. (2008). International human rights law: Struggling between apology and utopia. In A. Bullard (Ed.), Human rights in crisis (pp. 49-66). Hampshire, UK: Ashgate.

Butler, J. (2006). Precarious life: The powers of mourning and violence. New York: Verso.

Butler, J. (2012). Parting ways: Jewishness and the critique of Zionism. New York: Columbia University Press.

Cacho, L. M. (2012). Social death: Racialized rightlessness and the criminalization of the unprotected. New York: New York University Press.

Chomsky, N. (2012). Making the future: Occupations, interventions, empire and resistance. San Francisco: City Lights Books. 
Davidson, G. (2012). Torture as foreign policy: The Omar Khadr decision. In J. Williamson (Ed.), Omar Khadr, Oh Canada (pp. 254-264). Montreal \& Kingston: McGill-Queen's University Press.

Davis, A. Y. (2012). The meaning of freedom and other difficult dialogues. San Francisco: City Lights Books.

Des Rosiers, N. (2012). Pray or pay: The rights of Canadians abroad. In J. Williamson (Ed.), Omar Khadr, Oh Canada (pp. 369-375). Montreal \& Kingston: McGill-Queen's University Press.

Dua, E., Razack, N., \& Nyasha Warner, J. (2005). Race, racism, and empire: Reflections on Canada. Social Justice 23(4), 1-10.

Edney, D. (2012). The politics of fear. In J. Williamson (Ed.), Omar Khadr, Oh Canada (pp. 270-275). Montreal \& Kingston: McGill-Queen's University Press.

Engler, Y. (2012). The ugly Canadian: Stephen Harper's foreign policy. Vancouver: RED Publishing.

Evans, B., \& Giroux, H. A. (2015). Disposable futures: The seduction of violence in the age of spectacle. San Francisco: City Lights Books.

Falk, R. (2009). Achieving human rights. New York: Routledge.

Faulks, K. (2000). Citizenship. London: Routledge.

Fossum, J. E. (1999). Citizenship, diversity, and pluralism: The case of the European Union. In A. C. Cairns, J. C. Courtney, \& P. MacKinnon (Eds.), Citizenship, diversity, and pluralism: Canadian and comparative perspectives (pp. 202-230). Montreal and Kingston: McGillQueen's University Press.

Foucault, M. (2003). "Society must be defended": Lectures at the College de France. New York: Picador.

Free Omar Khadr Now Committee. (2013, December 13). Today Omar's security classification changed to medium. Free Omar Khadr Now. Retrieved from https://freeomar.ca/2013/12/13/today-omars-security-classification-changed-to-medium/

Gilroy, P. (1991). There ain't no black in the Union Jack: The cultural politics of race and nation. Chicago: University of Chicago Press.

Gregory, D. (2007). Vanishing points. In D. Gregory \& A. Pred (Eds.), Violent geographies: Fear, terror, and political violence (pp. 205-236). New York: Routledge.

Heater, D. (1999). What is citizenship? Cambridge: Polity Press.

Hitchens, C. (2001/2012). The trial of Henry Kissinger. Toronto: McClelland \& Stewart.

Hyndman, J. (2010). The question of 'the political' in critical geopolitics: Querying the 'child soldier' in the 'war on terror'. Political Geography 29, 247-255.

Jiwani, Y. (2005). The Great White North encounters September 11: Race, gender, and nation in Canada's national daily, The Globe and Mail. Social Justice 32(4), 50-68.

Jiwani, Y. (2011). Trapped in the carceral net: Race, gender, and the "War on Terror". Global Media Journal - Canadian Edition 4(2), 13-31.

Joppke, C. (2001). The evolution of alien rights in the United States, Germany, and the European Union. In T.A. Aleinikoff \& D. Klusmeyer (Eds.), Citizenship today: Global perspectives and practices (pp.36-62). Washington, D.C.: Brookings Institution Press.

Kennedy, D. (2004). The dark side of virtue: Reassessing international humanitarianism. Princeton: Princeton University Press.

Khan, S. (2012). Politics over principles: The case of Omar Khadr. In J. Williamson (Ed.), Omar Khadr, Oh Canada (pp. 51-66). Montreal \& Kingston: McGill-Queen's University Press.

Kohn, J. (n.d.). Totalitarianism: The inversion of politics. In three essays: The role of experience in Hannah Arendt's political thought. Washington, DC: The Library of Congress. Retrieved from http://memory.loc.gov/ammem/arendthtml/essayb1.html

LEGISinfo. (2016). C-6: An Act to amend the Citizenship Act and to make consequential amendments to another Act. Retrieved from http://www.parl.gc.ca/LegisInfo/BillDetails.aspx?Language $=$ E\&Mode $=1 \&$ Bill $=$ C6\&Parl $=4$ $2 \& \operatorname{Ses}=1$

Levant, E. (2011). The enemy within: Terror, lies, and the whitewashing of Omar Khadr. New York: McClelland \& Stewart. 
Levy, D., \& Sznaider, N. (2010). Human rights and memory. Pennsylvania: The Pennsylvania State University Press.

Macklin, A. (2012). The rule of law, the force of law, and the rule of force. In J. Williamson (Ed.), Omar Khadr, Oh Canada (pp. 222-246). Montreal \& Kingston: McGill-Queen's University Press.

Odartey-Wellington, F. (2009). Racial profiling and moral panic: Operation Thread and the AlQaeda sleeper cell that never was. Global Media Journal - Canadian Edition 2(2), 25-40.

Olund, E. N. (2007). Cosmopolitanism's collateral damage. In D. Gregory \& A. Pred (Eds.), Violent geographies: Fear, terror, and political violence (pp. 55-76). New York: Routledge.

Painter, J., \& Philo, C. (1995). Spaces of citizenship: An introduction. Political Geography 14(2), 107-120.

Pardy, G. (2012). The long way home: The saga of Omar Khadr. In J. Williamson (Ed.), Omar Khadr, Oh Canada (pp. 67-85). Montreal \& Kingston: McGill-Queen's University Press.

Perkel, C. (2016, February 18). Trudeau government drops appeal of Omar Khadr's bail. The Globe and Mail. Retrieved from http:/www.theglobeandmail.com/news/politics/ottawadrops-appeal-of-omar-khadrs-bail/article28804868/

Razack, S. H. (1998). Looking White people in the eye: Gender, race, and culture in courtrooms and classrooms. Toronto: University of Toronto Press.

Razack, S. H. (2000). From the "Clean Snows of Petawawa": The violence of Canadian peacekeepers in Somalia. Cultural Anthropology 15(1), 127-163.

Razack, S. H. (2008). Casting out: The eviction of Muslims from Western law and politics. Toronto: University of Toronto Press.

Razack, S. H. (2010). Abandonment and the dance of race and bureaucracy in spaces of exception. In S. Thobani, S. Razack, \& M. Smith (Eds.), States of race: Critical race feminism in the $21^{\text {st }}$ century (pp. 87-107). Toronto: Between the Lines.

Ross, A. (2008). The body counts: Civilian casualties and the crisis of human rights. In A. Bullard (Ed.), Human rights in crisis (pp. 35-48). Hampshire, UK: Ashgate.

Rygiel, K. (2010). Globalizing citizenship. Vancouver: UBC Press.

Said, E. W. (1981). Covering Islam: How the media and the experts determine how we see the rest of the world. New York: Pantheon Books.

Shephard, M. (2008). Guantanamo's child. Mississauga, ON: John Wiley \& Sons.

Shephard, M. (2013, May 29). Omar Khadr segregated from other inmates after death threats in Canadian prison. Toronto Star. Retrieved from http://www.thestar.com/news/world/2013/05/29/omar_khadr_segregated_from_other_inma tes_after_death_threats_in_canadian_prison.html

Tambakaki, P. (2009). From citizenship to human rights: The stakes for democracy. Citizenship Studies 13(1), 3-15.

The Canadian Press (2015, September 26). Toronto 18's Zakaria Amara among $1^{\text {st }}$ to lose citizenship under Bill C-24. CBCNews Canada. Retrieved from http://www.cbc.ca/news/Canada/Toronto-18-ringleader-citizenship-1.3245319

Thobani, S. (2007). Exalted subjects: Studies in the making of race and nation in Canada. Toronto: University of Toronto Press.

Vincent, A. (2010). The politics of human rights. Oxford: Oxford University Press.

Williamson, J. (2012). Introduction: The story so far. In J. Williamson (Ed.), Omar Khadr, Oh Canada (pp. 3-48). Montreal \& Kingston: McGill-Queen's University Press.

Zine, J. (2012). Stolen youth: Lost boys and imperial wars. In J. Williamson (Ed.), Omar Khadr, Oh Canada (pp. 390-411). Montreal \& Kingston: McGill-Queen's University Press.

Zizek, S. (1993). Tarrying with the negative: Kant, Hegel, and the critique of ideology, postcontemporary interventions. Durham: Duke University Press. 